\title{
The chemical composition of tertiary Indian coal ash and its combustion behaviour - a statistical approach: Part 2
}

\author{
Arpita Sharma ${ }^{1}$, Ananya Saikia ${ }^{1}$, Puja Khare ${ }^{2}$, D K Dutta ${ }^{1}$ and B P Baruah ${ }^{1, *}$ \\ ${ }^{1}$ Coal Chemistry Division, CSIR-North East Institute of Science 83 Technology, Jorhat 785 006, India. \\ ${ }^{2}$ Agronomy-Soil Division, CSIR-CIMAP, Lucknow 226 015, India. \\ ${ }^{*}$ Corresponding author.e-mail: bpbaruah@yahoo.com
}

In Part 1 of the present investigation, 37 representative Eocene coal samples of Meghalaya, India were analyzed and their physico-chemical characteristics and the major oxides and minerals present in ash samples were studied for assessing the genesis of these coals. Various statistical tools were also applied to study their genesis. The datasets from Part 1 used in this investigation (Part 2) show the contribution of major oxides towards ash fusion temperatures (AFTs). The regression analysis of high temperature ash (HTA) composition and initial deformation temperature (IDT) show a definite increasing or decreasing trend, which has been used to determine the predictive indices for slagging, fouling, and abrasion propensities during combustion practices. The increase or decrease of IDT is influenced by the increase of $\mathrm{Fe}_{2} \mathrm{O}_{3}, \mathrm{Al}_{2} \mathrm{O}_{3}, \mathrm{SiO}_{2}$, and $\mathrm{CaO}$, respectively. Detrital-authigenic index (DAI) calculated from the ash composition and its relation with AFT indicates Sialoferric nature of these coals. The correlation analysis, Principal Component Analysis (PCA), and Hierarchical Cluster Analysis (HCA) were used to study the possible fouling, slagging, and abrasion potentials in boilers during the coal combustion processes. A positive relationship between slagging and heating values of the coal has been found in this study.

\section{Introduction}

The organic components of coal are fundamental to define the nature of coal while the inorganic constituents contribute to the unwanted abrasion, slagging, and corrosion associated with coal combustion. The incorporated inorganic constituents (mineral matter) present in coal (Ward 2002) are responsible for most of the environmental problems associated with coal utilization. The characterization of coal ash for its tendency to form slag and foul has been related to the total mineral content, composition of coal, and ash fusion temperatures (AFTs) which are important parameters for the coal industry. The AFT partially reflects the extent of ash agglomeration during coal conversion, e.g., combustion, gasification, liquefaction, and ash-utilization processes. The formation of melts, sinters, and slag in combustion and gasification processes are responsible for significant operational and maintenance problems thereby increasing the cost and reducing the efficiency. A large number of studies have reported the relation of AFT with chemical and mineral composition of coal ash, and a relationship has been established to predict the melting behaviour of the ash (Vassilev et al. 1995; Vassileva and Vassilev 2002). The effects of major oxides, the ratio of silica-alumina

Keywords. Ash Fusion Temperature (AFT); Detrital-authigenic index (DAI); fouling; slagging; abrasion indices. 
$\left(\mathrm{SiO}_{2} / \mathrm{Al}_{2} \mathrm{O}_{3}\right)$ as well as acid and basic fluxes on the AFTs of coal ashes have been studied by different methods ( $\mathrm{Li}$ et al. 2006; Song et al. 2009, 2010). Mineral conversion occurring in the process of fusion has a great impact on AFT (Yang et al. 2006). Many investigations have focused on the study of the coal ash fusibility to predict its behavior during thermal processes (Huffman et al. 1981; Benson et al. 1993; Lloyd et al. 1993). It is possible to make a reliable prediction of ash fusion characteristics on the basis of the major oxides in coal ash and its initial deformation temperature (IDT) in particular, having significant implications in marketing and furnace design. The abundance of hydroxides, sulphates, carbonates, phosphates, and trace elements present in coal may also affect the environment by contaminating the surface and subsoil water (Vassilev and Vassileva 2007) and become bio-available during conversion processes. Slagging and fouling inside a combustion boiler renders poor heat exchange and obstructs the gas flow, leading to load reduction and eventual shut down. Various laboratory tests such as sinter strength test (Final report, European Commission Directorate-General XIII Telecommunications, 1994) can be used to estimate the ash fouling propensities. $\mathrm{MgO}, \mathrm{CaO}$, and dolomite present may reduce ash fouling propensities under the test conditions.

The fuel additives can reduce the deposition and corrosion problems of the boiler by addition of $\mathrm{MgO}$ or $\mathrm{CaCO}_{3}$; or by inducing crystal growth in liquid phases in a deposit to increase viscosity and thus reduce slagging (e.g., adding copper oxychloride); or help in removal of sulphur from coal (Final report, European Commission Directorate-General XIII Telecommunications, 1994).

Though tertiary Indian coals have been studied by several researchers (Mishra and Ghosh 1996; Singh and Singh 2000; Singh et al. 2012a, b, 2013), there is lack of information available on the fusibility of ash of these coals during combustion. Therefore, in this investigation, the Meghalaya coal ash samples were studied in terms of their chemical compositions, ash-fusion temperatures, and possible formation of slagging and fouling during utilization. The correlation trends between ash fusibility (IDT) and major oxides present in these coals have been discussed. In Part 1 of the present investigation, the genesis of the tertiary Indian coals with the help of major oxides of coal ash, ash yield and their relationship has been discussed using various statistical tools. The geology, coal occurrences of the studied area, the physicochemical properties, and the coal ash compositions have also been reported in Part 1 of this investigation.

\subsection{Brief account of petrographic and chemical characteristics of northeast Indian coals}

The northeastern Indian coals are characterized by low ash, high sulphur, high volatile matter, low ash fusion temperature, and high tar yield in comparison to other Indian coals. The sulphur content in these coals is in the range of $2-8 \%$ where majority is organically bound to the coal structure (70-95\%). It has been reported (Baruah 2008, 2009) that in northeastern Indian coals, the major minerals $(>5 \%)$ are identified in the crystalline matter of coal are quartz, kaolin, illite, feldspar, calcite, pyrite, and gypsum. These tertiary coals are characterized by high vitrinite content $(80 \%$ average), with the non-vitrinite fraction being predominantly inertinite which is low in proportion. The liptinite content is usually found to be less than 20\% (Sharma et al. 2012).

The composition of major oxides found in the studied coal ashes are in the range of $\mathrm{SiO}_{2}(37.78-68.18 \%), \mathrm{Fe}_{2} \mathrm{O}_{3}(7.05-28.69 \%), \mathrm{Al}_{2} \mathrm{O}_{3}$ (7.83-33.22\%), $\mathrm{CaO}(0.11-0.96 \%), \mathrm{MgO}(0.24-$ $1.27 \%), \quad \mathrm{TiO}_{2}(0.08-1.91 \%), \mathrm{SO}_{3}(0.15-1.48 \%)$, $\mathrm{P}_{2} \mathrm{O}_{5}(0.15-2.95 \%)$, and others $(0.16-14.33 \%$ of $\mathrm{K}_{2} \mathrm{O}$ and $\mathrm{Na}_{2} \mathrm{O}$ ). The minerals present in these coal samples are silicates, carbonates, phosphates, hydroxides, oxides, sulfates, and sulphides which have also been reported earlier (Nayak 2013). The minerals found in Meghalaya coals are shown in table 1.

\section{Experimental}

The 37 freshly mined coal samples from different coalfields of Meghalaya were subjected to proximate, ultimate analyses, done by proximate analyzer (TGA 701, Leco, USA), CHN analyzer (Truspec, Leco, USA) and Sulphur Determinator (S-144 DR, Leco, USA), respectively. The calorific values $(\mathrm{CV})$ of all the coal samples have been determined by Automatic Bomb Calorimeter (Leco AC350, USA) and the high temperature ash (HTA) analysis was carried out following standard methods (IS: 1355-1959) respectively. The complete data for chemical analysis are reported in Part 1 of this investigation. The studied coal samples are characterized by low to medium ash (4.1$26.9 \%$ ), high volatile matter $(22.8-38.89 \%)$, high sulphur (2.87-6.96\%) content, and high calorific values $(4035-6990 \mathrm{kcal} / \mathrm{kg})$.

The ash fusion temperature (AFT) measurements were carried out as per Indian Standard procedure (IS: 12891-1990) using Leitz Wetzlar ash fusion point determination apparatus at maximum temperature of $1600^{\circ} \mathrm{C}$. This experiment is carried out in a reducing environment at a 
Table 1. Mineral matters present in Meghalaya coal ash.

\begin{tabular}{ll}
\hline Silicates & \\
Quartz & $\mathrm{SiO}_{2}$ \\
Mica & $\mathrm{KAl}_{2} \mathrm{AlSi}_{3} \mathrm{O}_{10}(\mathrm{OH}, \mathrm{F})_{2}$ \\
Feldspar & $\mathrm{KAlSi}_{3} \mathrm{O}_{8}$ \\
Kaolinite & $\mathrm{Al}_{2} \mathrm{Si}_{2} \mathrm{O}_{5}[\mathrm{OH}]_{4}$ \\
Chlorite & $(\mathrm{Mg}, \mathrm{Fe})_{5} \mathrm{Al}_{2} \mathrm{Si}_{3} \mathrm{O}_{10}(\mathrm{OH})_{8}$ \\
Sulfides & \\
Pyrite & $\mathrm{FeS}_{2}$ \\
Marcasite & $\mathrm{FeS}_{2}$ \\
Sphalertite & $\mathrm{ZnS}_{\text {Phosphates }}$ \\
Apatite & \\
Monazite & $\mathrm{Ca}_{5} \mathrm{~F}\left(\mathrm{PO}_{4}\right)_{3}$ \\
Carbonates & $\left(\mathrm{Ce}, \mathrm{La}_{2} \mathrm{Th}_{,} \mathrm{Nd}\right) \mathrm{PO}_{4}$ \\
Calcite & \\
Siderite & $\mathrm{CaCO}_{3}$ \\
Sulfates & $\mathrm{FeCO}_{3}$ \\
Gypsum & \\
Barite & $\mathrm{CaSO}_{4} \cdot 2 \mathrm{H}_{2} \mathrm{O}$ \\
Oxides & $\mathrm{BaSO}_{4}$ \\
Hematite & \\
Rutile & $\mathrm{Fe}_{2} \mathrm{O}_{3}$ \\
Hydroxides & $\mathrm{TiO}_{2}$ \\
Gibbsite & \\
Geothite & $\mathrm{Al}(\mathrm{OH})_{3}$ \\
\hline
\end{tabular}

rate of $10^{\circ} \mathrm{C} / \mathrm{min}$ up to $1000^{\circ} \mathrm{C}$, and then by changing the heating rate to $5^{\circ} \mathrm{C} / \mathrm{min}$. During the process, the initial deformation temperature (IDT), hemispherical temperature (HT), and final fusion temperature (FT) were recorded according to the specific shapes of the ash cylinder. The ash fusion temperature (AFT) of the individual coal samples was determined and reported in table 2 .

The statistical analyses such as correlation coefficient, Principal Component Analysis (PCA), and Hierarchical Cluster Analysis (HCA) were performed using SPSS16 and XLSTATS software.

\section{Results and discussions}

\subsection{Relationship between major oxides} and ash-fusion temperatures (AFT) of coals

The initial deformation (ID), hemispherical (HT) and flow (FT) ash-fusion temperatures of the coals under study are shown in table 2 and found to be $1180^{\circ}-1290^{\circ}, 1425^{\circ}-1520^{\circ}$ and $1480^{\circ}-1530^{\circ} \mathrm{C}$, respectively. In this study, the observations are mostly made considering the initial deformation temperature (IDT), where most of the melting takes place in this temperature range and therefore
Table 2. Ash fusion temperatures (AFT) of the Meghalaya coal ash samples.

\begin{tabular}{|c|c|c|c|}
\hline Coal samples & $\begin{array}{l}\text { IDT } \\
\left({ }^{\circ} \mathrm{C}\right)\end{array}$ & $\begin{array}{c}\mathrm{HT} \\
\left({ }^{\circ} \mathrm{C}\right)\end{array}$ & $\begin{array}{c}\mathrm{FT} \\
\left({ }^{\circ} \mathrm{C}\right)\end{array}$ \\
\hline M1 & 1260 & 1480 & 1500 \\
\hline M2 & 1290 & 1440 & 1490 \\
\hline M3 & 1190 & 1490 & 1500 \\
\hline M4 & 1210 & 1490 & 1500 \\
\hline M5 & 1250 & 1500 & 1510 \\
\hline M6 & 1280 & 1490 & 1510 \\
\hline M7 & 1280 & 1480 & 1520 \\
\hline M8 & 1240 & 1450 & 1520 \\
\hline M9 & 1300 & 1465 & 1480 \\
\hline M10 & 1250 & 1475 & 1530 \\
\hline M11 & 1220 & 1452 & 1490 \\
\hline M12 & 1230 & 1435 & 1480 \\
\hline M13 & 1210 & 1425 & 1530 \\
\hline M14 & 1210 & 1405 & 1480 \\
\hline M15 & 1230 & 1470 & 1520 \\
\hline M16 & 1260 & 1430 & 1480 \\
\hline M17 & 1250 & 1480 & 1500 \\
\hline M18 & 1180 & 1475 & 1488 \\
\hline M19 & 1190 & 1480 & 1510 \\
\hline M20 & 1200 & 1480 & 1500 \\
\hline M21 & 1190 & 1470 & 1500 \\
\hline M22 & 1180 & 1490 & 1520 \\
\hline M23 & 1260 & 1520 & 1520 \\
\hline M24 & 1240 & 1475 & 1510 \\
\hline M25 & 1290 & 1390 & 1480 \\
\hline M26 & 1220 & 1480 & 1500 \\
\hline M27 & 1270 & 1490 & 1500 \\
\hline M28 & 1290 & 1485 & 1500 \\
\hline M29 & 1250 & 1500 & 1500 \\
\hline M30 & 1190 & 1460 & 1500 \\
\hline M31 & 1190 & 1475 & 1490 \\
\hline M32 & 1180 & 1470 & 1500 \\
\hline M33 & 1210 & 1440 & 1480 \\
\hline M34 & 1220 & 1480 & 1500 \\
\hline M35 & 1210 & 1500 & 1530 \\
\hline M36 & 1170 & 1480 & 1500 \\
\hline M37 & 1200 & 1500 & 1520 \\
\hline
\end{tabular}

IDT: Initial deformation temperature, HT: hemispherical temperature, FT: final fusion temperature.

low ash fusion temperatures are seen (table 2) and rarely does the final temperature exceed $>1500^{\circ} \mathrm{C}$. In this investigation, the HT and FT are not considered as they exhibit similar results when compared with the major oxides. The AFTs of coals largely depend upon the chemical composition of ash. The AFT is applied for understanding the fusion behaviour of the coal ashes and is based on the measurement of three key temperatures describing the softening and melting behaviour of ash. 
The main constituents of coal ash are silica, alumina and iron oxides with small percentages of other oxides such as $\mathrm{CaO}, \mathrm{MgO}$, alkalies, etc. The ash fusibility is reported to be a function of these major oxides present in coal ash. The coal ash fusibility characteristics are difficult to determine precisely, partly because many of the coal ash components do not have a sharp melting point like a pure compound. The melting point of alumina and silica is around $1600^{\circ}-1700^{\circ} \mathrm{C}$ (Dutta Roy 1940). The other components such as $\mathrm{Fe}_{2} \mathrm{O}_{3}, \mathrm{CaO}, \mathrm{MgO}$, and alkalies act as a flux upon $\mathrm{Al}_{2} \mathrm{O}_{3}$ and $\mathrm{SiO}_{2}$ reducing the fusion point of ash. The fusion point generally varies according to the ratio between the acidic components and the bases $\left(\mathrm{SiO}_{2}+\mathrm{Al}_{2} \mathrm{O}_{3}+\right.$ $\left.\mathrm{TiO}_{2} / \mathrm{Fe}_{2} \mathrm{O}_{3}+\mathrm{CaO}+\mathrm{MgO}+\mathrm{K}_{2} \mathrm{O}+\mathrm{Na}_{2} \mathrm{O}\right)$. Greater the ratio the higher is the fusion point (Dutta Roy 1940). It is reported that higher the $\mathrm{SiO}_{2}$ concentrations, higher the melting point, but in this case (table 2), the fusion is lowered by the presence of other oxides like $\mathrm{MgO}, \mathrm{CaO}$ and alkaline oxides. Moreover, the ratio between the acidic components and bases of these coals is found to be 3.23 indicating low ash fusion temperatures of these coals. The fusion temperature of these coals is comparatively lower than that of the Jharia and Raniganj coalfields range, from 9.50 to 3.26 (Dutta Roy 1940). The chemical composition of the major inorganic oxides present in the high temperature coal ash can be used for their classification as sialic, ferrisialic, ferricalcisialic, and calsialic (Vassilev and Vassileva 2009; Singh et al. 2011, 2012a, b). The studied coal samples belong to the high and medium acid groups of sialic, ferrisialic, and calsialic types of high temperature ash (figure 1).

The influence of the chemical composition of Meghalaya coal ash samples on their fusibility was assessed by the regression plots of coal ash composition with IDT (figure 2). Significant correlation is observed between the major oxides and AFTs separately. Positive correlations with IDT are shown by $\mathrm{Fe}_{2} \mathrm{O}_{3}\left(R^{2}=0.529\right)$ and $\mathrm{Al}_{2} \mathrm{O}_{3}\left(R^{2}=0.5397\right)$ (figure 2b, c) whereas $\mathrm{SiO}_{2}\left(R^{2}=-0.7757\right)$ and $\mathrm{CaO}$ $\left(R^{2}=-0.6882\right)$ are negatively correlated with IDT (figure 2a, d) respectively. From the literature study, it is found that $\mathrm{SiO}_{2}$ and $\mathrm{Al}_{2} \mathrm{O}_{3}$ concentrations increase the AFTs but in our investigation the higher concentration of $\mathrm{SiO}_{2}$ decreases the IDT, while IDT is moderately increased with higher concentration of $\mathrm{Al}_{2} \mathrm{O}_{3}$. Significant interpretation cannot be drawn from individual major oxides with AFT as their relation with fusibility is not found to be of a definite trend. If $\mathrm{SiO}_{2}$ and $\mathrm{Al}_{2} \mathrm{O}_{3}$ are present alone, they increase the melting point of the coal ash. The other oxides such as $\mathrm{Fe}_{2} \mathrm{O}_{3}, \mathrm{CaO}, \mathrm{MgO}$, and other alkalis may affect the fusibility of ash by acting as a flux, which might be the cause for reduction in IDT. The presence of these oxides is also evidenced by the presence of the silicate minerals [quartz $\left(\mathrm{SiO}_{2}\right)$, feldspar $\left(\mathrm{KAlSi}_{3} \mathrm{O}_{8}-\mathrm{NaAlSi}_{3} \mathrm{O}_{8}-\mathrm{CaAl}_{2} \mathrm{Si}_{2} \mathrm{O}_{8}\right)$, chlorite $((\mathrm{Mg}$, $\left.\mathrm{Fe})_{5} \mathrm{Al}_{2} \mathrm{Si}_{3} \mathrm{O}_{10}(\mathrm{OH})_{8}\right)$, and kaolinite $\left.\left(\mathrm{Al}_{2} \mathrm{Si}_{2} \mathrm{O}_{5}(\mathrm{OH})_{4}\right)\right]$, carbonates [calcite $\left(\mathrm{CaCO}_{3}\right)$ ], phosphates [monazite (Ce, La, Th, Nd) $\mathrm{PO}_{4}$ and apatite $\left(\mathrm{Ca}_{5} \mathrm{~F}\left(\mathrm{PO}_{4}\right)_{3}\right]$, hydroxides [gibbsite $\mathrm{Al}(\mathrm{OH})_{3}$ ], oxides [hematite

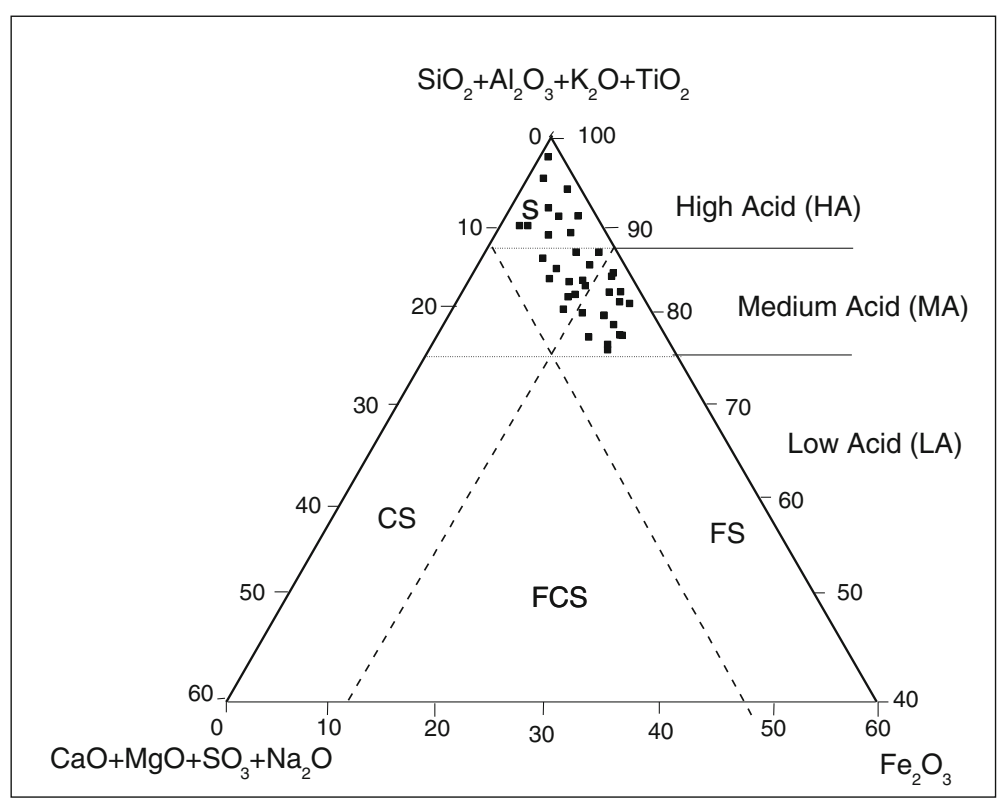

Figure 1. Chemical classification and genetic mineral classification systems of high temperature ash. (S: Sialic, FS: Ferrisialic, FCS: Ferricalsialic, CS: Calsialic.) 


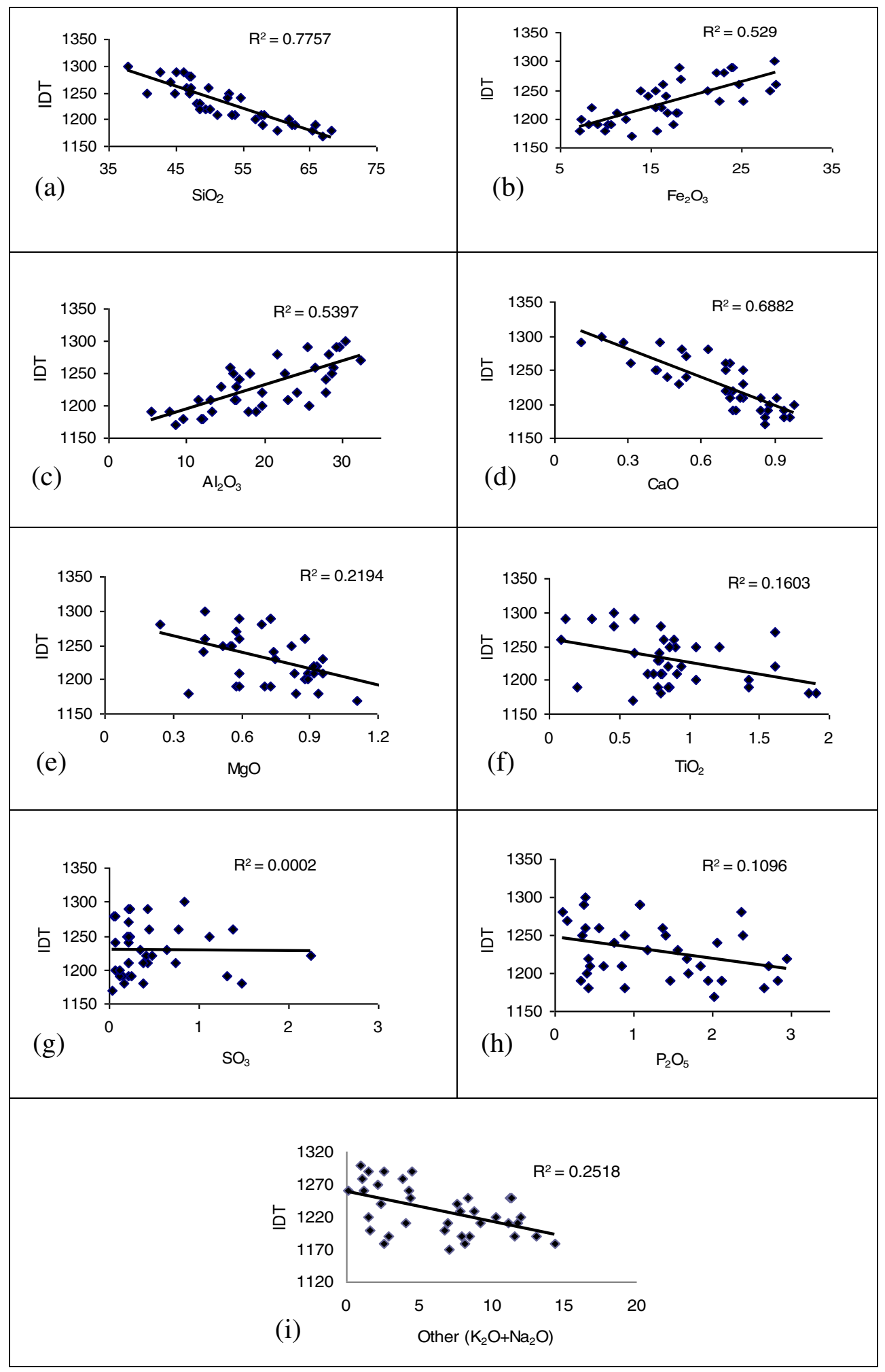

Figure 2. Correlation trends between initial deformation temperatures (ID) and (a) $\mathrm{SiO}_{2}$, (b) $\mathrm{Fe}_{2} \mathrm{O}_{3}$, (c) $\mathrm{Al}_{2} \mathrm{O}_{3}$, (d) $\mathrm{CaO}_{\text {, }}$ (e) $\mathrm{MgO}$, (f) $\mathrm{TiO}_{2}$, (g) $\mathrm{SO}_{3}$, (h) $\mathrm{P}_{2} \mathrm{O}_{5}$, and (i) others $\left(\mathrm{K}_{2} \mathrm{O}+\mathrm{Na}_{2} \mathrm{O}\right)$.

$\left(\mathrm{Fe}_{2} \mathrm{O}_{3}\right)$ and rutile $\left(\mathrm{TiO}_{2}\right)$ ], sulfates [gypsum $\left.\left(\mathrm{CaSO}_{4} \cdot 2 \mathrm{H}_{2} \mathrm{O}\right)\right]$, and sulphides [pyrites $\left(\mathrm{FeS}_{2}\right)$, marcasites $\left(\mathrm{FeS}_{2}\right)$, and sphalerites (ZnS)] (Nayak 2013). The mineralogical data analysis has also evidenced the presence of higher concentration of major oxides of $\mathrm{Fe}_{2} \mathrm{O}_{3}$ and $\mathrm{Al}_{2} \mathrm{O}_{3}$, which may be responsible for the increase of the initial deformation temperature. However, from the study of major oxides of these coal ashes, it is found that the concentration of $\mathrm{SiO}_{2}$ is more than $\mathrm{Fe}_{2} \mathrm{O}_{3}$ and 
$\mathrm{Al}_{2} \mathrm{O}_{3}$ and as a result the IDT decreases with the increase of $\mathrm{SiO}_{2}$. The thermo-mechanical analysis (TMA) of ash at high temperature $\left(800^{\circ}-1600^{\circ} \mathrm{C}\right)$ which has not been done here may also indicate the ash fusion characteristics. However, at higher temperatures, mineral and phase transformations are observed. TMA measurements provided the rapid fusion events during ash fusion identified by different peaks which are related to formation of eutectics shown by appropriate phase diagrams (Gupta et al. 1998). Different thermodynamic computer models also may give information on the thermo-chemistry of the main minerals present in the coal ash such as $\mathrm{SiO}_{2}-\mathrm{Al}_{2} \mathrm{O}_{3}-$ $\mathrm{FeO}-\mathrm{Fe}_{2} \mathrm{O}_{3}-\mathrm{CaO}$ (Australian Coal Rev 1998) and transformation.

Coal ashes are normally classified as low melting $\left(<1300^{\circ} \mathrm{C}\right)$, medium melting $\left(1300^{\circ}-1450^{\circ} \mathrm{C}\right)$, and high melting $\left(>1450^{\circ} \mathrm{C}\right)$ AFT types according to the HT values (Vassilev et al. 1995). The coals under study have low to high melting ashes. According to the chemical classification systems for HTA (Vassilev et al. 1995; Vassilev and Vessileva 2009), a majority of the studied coal ash samples correspond to sialoferric type (figure 3). The studied low melting ashes of sialoferric type having higher proportion of $\mathrm{Si}, \mathrm{Al}$, $\mathrm{Fe}, \mathrm{Na}$, and $\mathrm{K}$ (mainly quartz, chlorite, kaolinite, pyrites and marcasites) and these oxides react with the silicates and probably form a large number of fluxing low temperature eutectic of $\mathrm{Fe}-\mathrm{Al}-\mathrm{Na}-\mathrm{K}$ silicate phases that start to melt intensively at $1170^{\circ}-1300^{\circ} \mathrm{C}$. The abundance of silicate minerals in these coals also contributes significantly to the

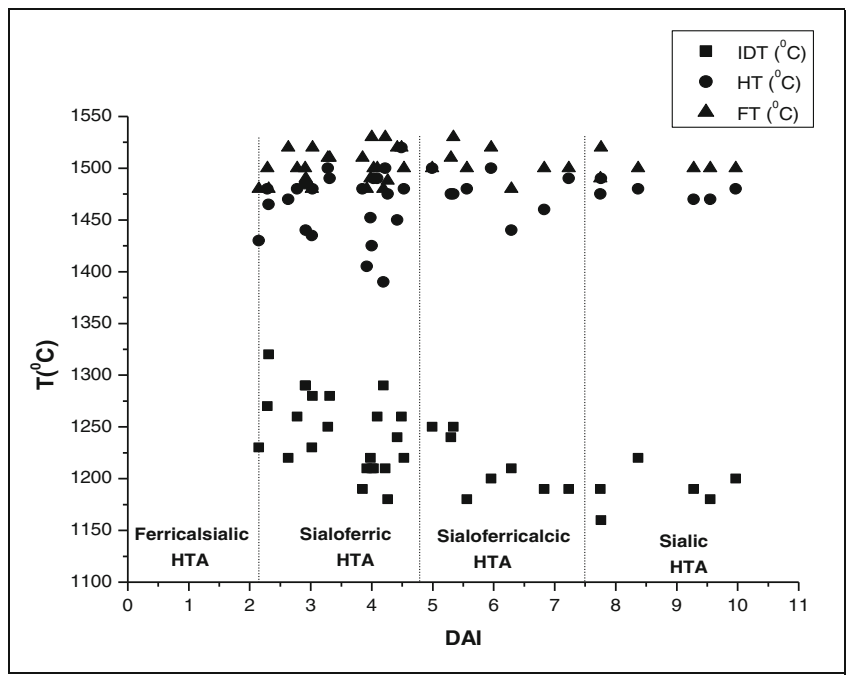

Figure 3. Correlation trends between detrital-authigenic indices (DAI) and ash-fusion temperatures (AFT) for Meghalaya coal ashes (37 numbers). low melting of their ashes (Vassileva and Vassilev 2002).

\subsection{Slagging, fouling and abrasion potentials of Meghalaya coal ash samples}

The fusion behaviour of coal ash is an important factor in determining the formation of slag deposits on the reactor surfaces. It may also have an influence on the nature of the fouling formation that can occur on surfaces during heat exchange. The slagging and fouling depositions cause corrosion and erosion of boiler tubes affecting heat transfer efficiency (Munir and Nimmo 2010). Most of the coal conversion technologies such as combustion and gasification face common challenges caused by slagging and fouling. The two essential factors controlling clinker formation, slagging, and fouling in coal conversion processes are: (a) operating conditions of the process and (b) the minerals that contain fluxing inorganic elements $(\mathrm{K}$, $\mathrm{Na}, \mathrm{Ca}, \mathrm{Fe}, \mathrm{Mg}$, etc.) in the coal (Van Dyk et al. 2006). The major elements including alkali metals $(\mathrm{K}, \mathrm{Na})$, alkaline earth metals $(\mathrm{Ca}, \mathrm{Mg})$, silicon, chlorine, and sulphur are involved in reactions leading to ash slagging and fouling (Heinzel et al. 1998; Fryda et al. 2010). The alkali elements (Na, K) are particularly important in the initiation of slag formation and its growth (Barnes 2009). Quartz and to some extent pyrite are the main minerals associated with the abrasion deposits. The presence of coarse-grained nonspherical quartz may be responsible for abrasion or erosion hazards in gasifiers and combustion furnaces (Reifenstein 1999).

The presence of basic compounds in coal ash $\left(\mathrm{Fe}_{2} \mathrm{O}_{3}+\mathrm{CaO}+\mathrm{MgO}+\mathrm{Na}_{2} \mathrm{O}+\mathrm{K}_{2} \mathrm{O}\right)$ lowers the melting temperature while the acidic compounds $\left(\mathrm{SiO}_{2}+\mathrm{Al}_{2} \mathrm{O}_{3}+\mathrm{TiO}_{2}\right)$ increase its melting temperature. The ratio of basic compounds to acidic compounds is considered as an index for slagging behaviour (Skorupska 1993; Vamvuka and Zografos 2004; Pronobis 2005; Kazagic and Smajevic 2007; Masia et al. 2007). The commonly used slagging and fouling indices have been reported below (Skorupska 1993; Vamvuka and Zografos 2004; Pronobis 2005).

\begin{tabular}{lll}
\hline Terms & \multicolumn{1}{c}{ Formula } & \multicolumn{1}{c}{ Range } \\
\hline Slagging & (Base/acid)X & $<0.6$, low slagging; \\
index & ( $\mathrm{S}$ dry $)$ & $0.6-2.0$, medium; \\
& & $2.0-2.6$, high; \\
& & $>2.6$, extremely high. \\
Fouling & $(\mathrm{Base} / \mathrm{acid}) \mathrm{X}$ & $\leq 0.6$, low fouling; \\
index & $\left(\mathrm{Na}_{2} \mathrm{O}+\mathrm{K}_{2} \mathrm{O}\right)$ & $0.6-40$, high; \\
& & $\geq 40$, extremely high. \\
\hline
\end{tabular}


$\mathrm{Fe}_{2} \mathrm{O}_{3}$ and $\mathrm{CaO}$ contents in coal ash are the important parameters for determining the slagging behaviour of coal. The slag formation is disturbed if the concentration of acid oxides in the coal samples is greater than the basic oxides (Akar and Itekoglu 2007). The coal samples under study show that the acid oxide contents (average $73.56 \%$ ) are more than the basic oxide contents (average $24.72 \%$ ), thereby having low slag forming potential. But as seen for these coals with high sulphur content, the slagging factor is found to be 1.51 (table 4), which is $>0.6$ (Akar and Itekoglu 2007).

The average slagging, fouling, and abrasion potentials of Meghalaya coal ash are 1.51, 0.15 and 3.37 , respectively (table 3). Based on the ranges given above, it is found that the Meghalaya coals have medium slagging with low fouling potential. The presence of high sulphur (average 4.29\%) in the studied coal samples also favours slag formation. In order to utilize these coals with slag

Table 3. Slagging, fouling and abrasion parameters of Meghalaya coals.

\begin{tabular}{|c|c|c|c|c|c|c|}
\hline \multirow[b]{2}{*}{ Coal samples } & \multicolumn{4}{|c|}{ Slagging potential } & \multirow{2}{*}{$\begin{array}{l}\text { Fouling potential } \\
\text { Fouling factor } \\
(\text { Base/acid }) \mathrm{X} \\
\left(\mathrm{Na}_{2} \mathrm{O}+\mathrm{K}_{2} \mathrm{O}\right)\end{array}$} & \multirow[b]{2}{*}{$\begin{array}{c}\text { Abrasion potential } \\
\text { silica/alumina ratio } \\
\qquad \mathrm{SiO}_{2} / \mathrm{Al}_{2} \mathrm{O}_{3}\end{array}$} \\
\hline & $\begin{array}{c}\text { Base/acid ratio } \\
\text { Base/acid }\end{array}$ & $\begin{array}{c}\mathrm{Fe} / \mathrm{Ca} \\
\mathrm{Fe}_{2} \mathrm{O}_{3} / \mathrm{CaO}\end{array}$ & $\begin{array}{l}\text { Silica ratio } \\
\mathrm{SiO}_{2} / \\
\text { SiFeCaMg }\end{array}$ & $\begin{array}{c}\text { Slagging factor } \\
\text { (Base/acid)X } \\
\text { (S dry) }\end{array}$ & & \\
\hline M1 & 0.35 & 79.45 & 0.65 & 1.79 & 2.20 & 1.76 \\
\hline M2 & 0.39 & 85.71 & 0.65 & 2.68 & 0.15 & 1.81 \\
\hline M3 & 0.31 & 14.09 & 0.85 & 2.180 & 0.03 & 8.40 \\
\hline M4 & 0.41 & 24.99 & 0.75 & 2.34 & 0.04 & 5.02 \\
\hline M5 & 0.38 & 27.62 & 0.67 & 2.13 & 0.09 & 2.09 \\
\hline M6 & 0.32 & 35.33 & 0.67 & 1.90 & 0.31 & 1.67 \\
\hline M7 & 0.40 & 44.15 & 0.66 & 2.14 & 0.10 & 2.19 \\
\hline M8 & 0.35 & 30.96 & 0.75 & 2.26 & 0.05 & 3.26 \\
\hline M9 & 0.44 & 150.47 & 0.56 & 2.38 & 0.45 & 1.24 \\
\hline M10 & 0.37 & 19.76 & 0.77 & 2.09 & 0.03 & 2.94 \\
\hline M11 & 0.25 & 22.05 & 0.73 & 0.69 & 0.16 & 1.78 \\
\hline M12 & 0.50 & 44.29 & 0.67 & 1.85 & 0.06 & 2.93 \\
\hline M13 & 0.46 & 21.26 & 0.73 & 2.66 & 0.04 & 4.11 \\
\hline M14 & 0.31 & 23.17 & 0.75 & 1.81 & 0.07 & 3.53 \\
\hline M15 & 0.54 & 32.71 & 0.64 & 2.59 & 0.07 & 3.38 \\
\hline M16 & 0.54 & 39.85 & 0.61 & 2.79 & 0.13 & 3.05 \\
\hline M17 & 0.70 & 66.78 & 0.58 & 2.06 & 0.06 & 2.57 \\
\hline M18 & 0.26 & 16.30 & 0.79 & 1.01 & 0.10 & 5.42 \\
\hline M19 & 0.39 & 23.58 & 0.77 & 1.70 & 0.05 & 11.38 \\
\hline M20 & 0.12 & 8.25 & 0.87 & 0.34 & 0.07 & 2.40 \\
\hline M21 & 0.29 & 9.29 & 0.87 & 0.84 & 0.02 & 4.68 \\
\hline M22 & 0.24 & 10.47 & 0.86 & 0.89 & 0.03 & 7.10 \\
\hline M23 & 0.23 & 23.36 & 0.74 & 0.84 & 0.19 & 1.74 \\
\hline M24 & 0.22 & 31.85 & 0.77 & 0.76 & 0.09 & 1.90 \\
\hline M25 & 0.31 & 165.18 & 0.70 & 1.02 & 0.07 & 1.52 \\
\hline M26 & 0.29 & 11.89 & 0.83 & 1.06 & 0.02 & 2.08 \\
\hline M27 & 0.27 & 33.81 & 0.69 & 1.05 & 0.13 & 1.37 \\
\hline M28 & 0.37 & 55.58 & 0.63 & 1.07 & 0.24 & 1.45 \\
\hline M29 & 0.33 & 37.83 & 0.73 & 1.04 & 0.04 & 1.57 \\
\hline M30 & 0.26 & 11.28 & 0.82 & 1.06 & 0.03 & 3.05 \\
\hline M31 & 0.17 & 10.76 & 0.85 & 0.66 & 0.06 & 3.68 \\
\hline M32 & 0.31 & 8.19 & 0.87 & 1.17 & 0.02 & 5.10 \\
\hline M33 & 0.26 & 12.43 & 0.80 & 0.81 & 0.04 & 2.31 \\
\hline M34 & 0.39 & 22.06 & 0.74 & 1.40 & 0.04 & 2.47 \\
\hline M35 & 0.43 & 22.18 & 0.74 & 1.26 & 0.04 & 3.15 \\
\hline M36 & 0.29 & 15.02 & 0.82 & 0.86 & 0.04 & 7.89 \\
\hline M37 & 0.27 & 12.39 & 0.80 & 0.84 & 0.03 & 2.89 \\
\hline Avg. for (M1-M37) & 0.34 & 35.25 & 0.74 & 1.51 & 0.15 & 3.37 \\
\hline
\end{tabular}

1. Base $=\mathrm{Fe}_{2} \mathrm{O}_{3}+\mathrm{CaO}+\mathrm{MgO}+\mathrm{K}_{2} \mathrm{O}+\mathrm{Na}_{2} \mathrm{O}, 2$. Acid $=\mathrm{SiO}_{2}+\mathrm{TiO}_{2}+\mathrm{Al}_{2} \mathrm{O}_{3}, 3 . \mathrm{SiFeCaMg}=\mathrm{SiO}_{2}+\mathrm{Fe}_{2} \mathrm{O}_{3}+\mathrm{CaO}+\mathrm{MgO}$. 
forming tendencies, fluidized bed combustion system would be the best choice to avoid slagging characteristics.

\subsection{Analysis of coal ash and its thermal behaviour}

\subsubsection{Correlation analysis}

Correlation coefficients have shown the interrelation among the coal ashes, calorific value, and the predictive indices. The Pearson correlations derived (table 4) for these datasets show that the slagging potential $(r=0.55)$ is positively correlated with the heating value of the coals. No other significant relation is found with the other characteristics of coal ash behaviour.

\subsubsection{Hierarchical clustering analysis ( $H C A$ )}

Cluster analysis is carried out to discriminate between ash and the thermal behaviour of these coals with mutually high similarity. In the dendrogram (figure 4), two major clusters are obtained. The first cluster comprises of two subsections including slagging potential, $\mathrm{CV}$, and fouling potential, while the second cluster has one subsection including ash and abrasion potential. In this analysis, it is found that the slagging behaviour and calorific value of Meghalaya coals that have pairwise similarities form a common group and this grouping is continued until all of them are contained in a single group.

\subsubsection{Principal Component Analysis (PCA)}

The ash content, slagging potential, fouling potential, abrasion potential, and $\mathrm{CV}$ were selected for the principal component analysis due to their continuity of measurement in time scale. In the application of principal component analysis to these datasets, a correlation matrix was used. As Chatfield and Collin (1980) stated, the components with an eigen value of $<1$ should be eliminated

Table 4. Bivariant analysis of ash behaviour of coal.

\begin{tabular}{lcccrr}
\hline Variables & Ash & $\begin{array}{c}\text { Slagging } \\
\text { potential }\end{array}$ & $\begin{array}{c}\text { Fouling } \\
\text { potential }\end{array}$ & $\begin{array}{c}\text { Abrasion } \\
\text { potential }\end{array}$ & CV \\
\hline Ash & $\mathbf{1}$ & 0.123 & -0.166 & 0.042 & -0.369 \\
Slagging potential & 0.123 & $\mathbf{1}$ & -0.045 & 0.007 & $\mathbf{0 . 5 4 5}$ \\
Fouling potential & -0.166 & -0.045 & $\mathbf{1}$ & -0.054 & 0.162 \\
Abrasion potential & 0.042 & 0.007 & -0.054 & $\mathbf{1}$ & -0.207 \\
CV & -0.369 & $\mathbf{0 . 5 4 5}$ & 0.162 & -0.207 & $\mathbf{1}$ \\
\hline
\end{tabular}

* The significant $r$ values at $99 \%$ confidence level are: $\geq 0.40$ and $\leq-0.40$ for 37 variables.

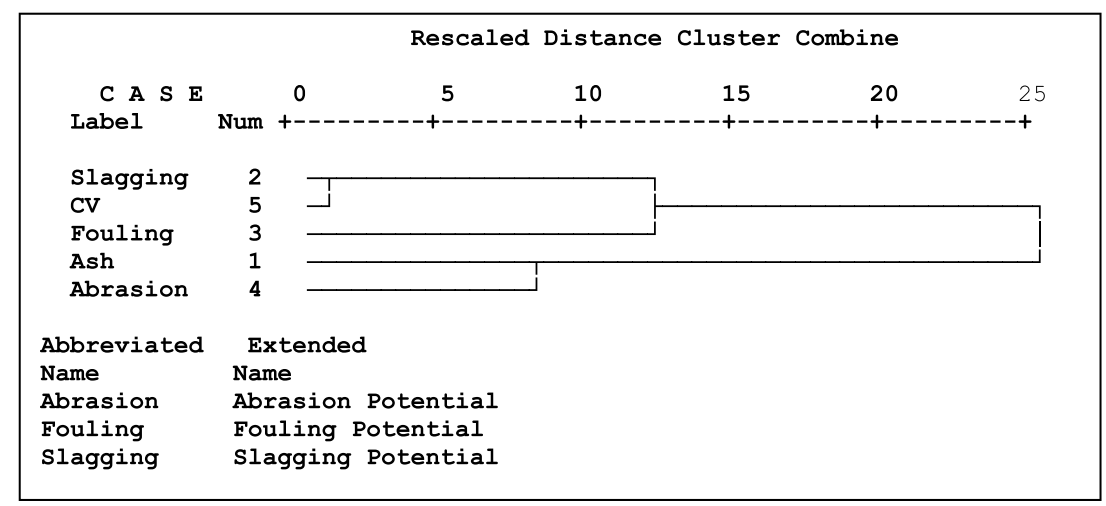

Figure 4. Hierarchical clustering analysis (HCA).

Table 5. Eigen values and \% variability by principal components.

\begin{tabular}{lrrrrr}
\hline & F1 & F2 & \multicolumn{1}{c}{ F3 } & F4 & \multicolumn{1}{c}{ F5 } \\
\hline Eigen value & 1.688 & 1.231 & 1.000 & 0.858 & 0.254 \\
Variability (\%) & 33.767 & 24.626 & 19.367 & 17.159 & 5.080 \\
Cumulative \% & 33.767 & 58.393 & 77.761 & 94.920 & 100.000 \\
\hline
\end{tabular}


Table 6. Results of principal component analysis.

\begin{tabular}{lrrr}
\hline & \multicolumn{1}{c}{ F1 } & \multicolumn{1}{c}{ F2 } & \multicolumn{1}{c}{ F3 } \\
\hline Ash & -0.483 & $\mathbf{0 . 6 2 9}$ & -0.258 \\
Slagging potential & $\mathbf{0 . 6 2 3}$ & $\mathbf{0 . 7 0 0}$ & 0.130 \\
Fouling potential & 0.320 & $\mathbf{- 0 . 5 5 2}$ & 0.169 \\
Abrasion potential & -0.327 & 0.169 & $\mathbf{0 . 9 4 1}$ \\
CV & $\mathbf{0 . 9 2 6}$ & 0.107 & 0.052 \\
\hline
\end{tabular}

so that fewer components are dealt with. The first two components are extracted and the other components are eliminated. When the percentages of the total variances of the three extracted components are accumulated, it can be seen that these three principal components account for $77.76 \%$ of the total variance of the original data (table 5). Only variables having loading more than 0.5 are considered to explain each factor (table 6).

From tables 5 and 6 , the factor 1 accounts for $33.77 \%$ of total variance in the observed variables and is associated with slagging potential and $\mathrm{CV}$. The high loading of $\mathrm{CV}$ reflects that slagging potential is related to it. HCA also shows the linkage between $\mathrm{CV}$ and slagging potential (figure 4). The major link between the CV and slagging index is coal ash oxides. It might be possible that increase in basic oxide as compared to acid oxide or sulphur content may cause the higher values of both. It is reported that sulphur may cause increase in the value of $\mathrm{CV}$ (Wynteri et al. 2004). The factor 2 accounts for $24.63 \%$ of the total variance with slagging potential, ash, and fouling potential (negatively). This factor indicates that ash and fouling potential are related to the slagging potential of the coal. The negative score of fouling potential indicates that with increase in slagging behaviour, the fouling potential of the Meghalaya coals decreases. Factor 3 accounts for 19.37\% of the total variance with high loading of abrasion potentials. The graphical representation of the Principal Component Analysis shows samples with similar behaviour (M1, M2, M3, etc.) and variables (ash, abrasion potential, slagging potential, etc.) through the score (figure 5a) and loading plots (figure 5b), respectively. By comparing the score plot and loading plot, the relationships between samples and variables are identified. In the plots, close variables are seen to have high correlation and show similar results for close samples. The variables on the opposite side of the origin are significantly negatively correlated while orthogonal variables have no relation. Samples on the right of these plots are dominated by the variables on the right and vice versa. The relationship between the score plot and loading plot is illustrated in the bi-plot diagram (figure 5c).
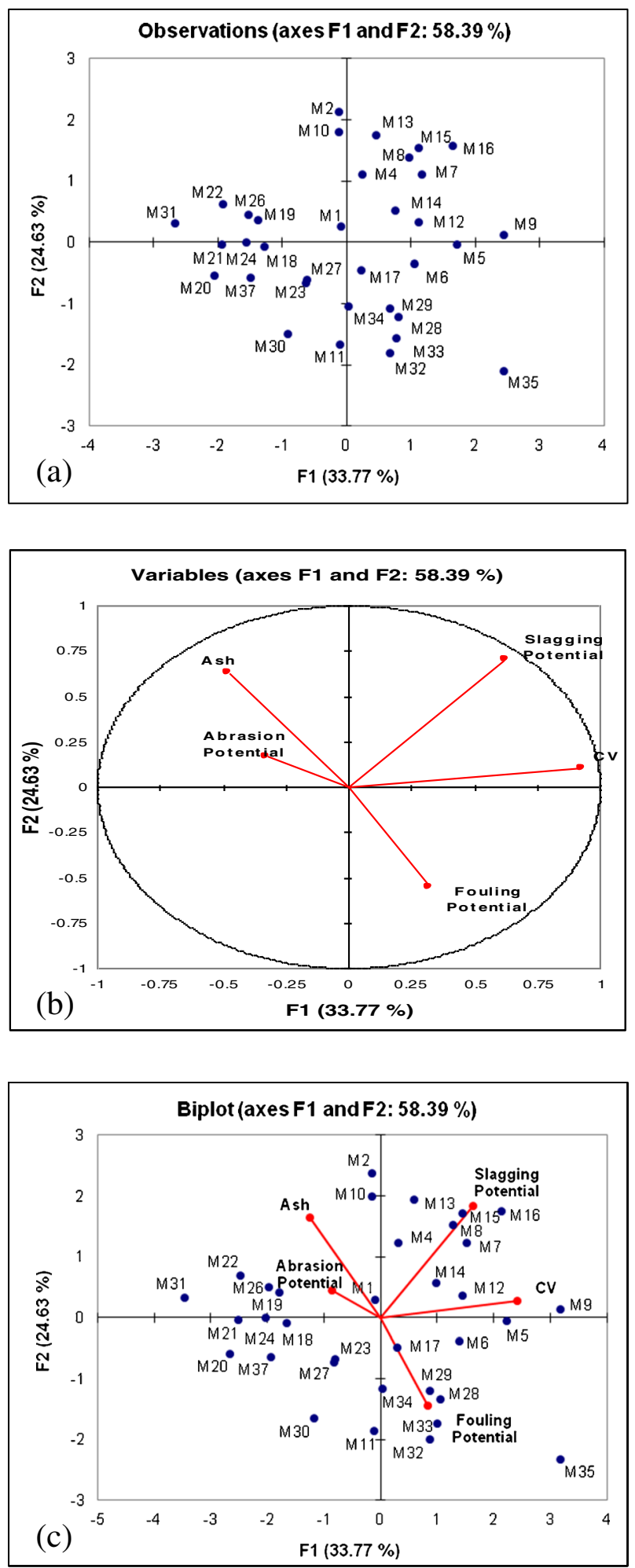

Figure 5. (a) Score plot, (b) loading plot and (c) bi-plot of principal component analysis (PCA).

\section{Conclusion}

The correlation trends between initial deformation temperature and the chemical composition of Meghalaya coal ash samples showed that the increase in the concentration of $\mathrm{Fe}_{2} \mathrm{O}_{3}$ and $\mathrm{Al}_{2} \mathrm{O}_{3}$ 
increases the IDT while the reverse is seen for $\mathrm{SiO}_{2}$ and $\mathrm{CaO}$. The presence of other oxides like $\mathrm{MgO}$, $\mathrm{P}_{2} \mathrm{O}_{5}, \mathrm{TiO}_{2}, \mathrm{SO}_{3}, \mathrm{Na}_{2} \mathrm{O}$, and $\mathrm{K}_{2} \mathrm{O}$ may also be significant for lower IDT. The coal samples belong to the high and medium acid groups of sialic, calsialic, and ferrisialic types of high temperature ash and are mostly low and high melting exhibiting sialoferric type. Based on the slagging and fouling ranges, it is found that the Meghalaya coals have medium slagging potential whereas these coals exhibit low fouling potentials. The study of correlation, HCA and PCA analyses among the ashes, calorific value, and predictive indices revealed that the slagging behaviour of the Meghalaya coals is found to correlate with the calorific values. The low ash fusibility of these coal ashes can be overcome in the combustion systems by adding fuel additives like $\mathrm{MgO}$ or $\mathrm{CaCO}_{3}$, or inducing crystal growth to increase viscosity and reduce slagging.

\section{Acknowledgements}

The authors are thankful to the Ministry of Steel, Govt. of India, New Delhi and CSIR, New Delhi for financial assistance.

\section{References}

Akar G and Itekoglu U 2007 Relationship between ash fusion temperature (AFT) and coal mineral matter in some Turkish coal ashes; Asian J. Chem. 21 2105-2109.

Benson S A, Hurley J P, Zygarlicke C J, Steadman E N and Erickson T 1993 Predicting ash behavior in utility boilers; Energy Fuels 7 746-754.

Barnes I 2009 Slagging and fouling in coal-fired boilers; CCC/147, 43p, ISBN 978-92-9029-466-5 (www.ieacoal. org.uk).

Baruah B P 2008 Environmental studies around Makum coalfield, Margherita (Thesis); Dibrugarh University, Assam, India; 118p.

Baruah B P 2009 Environmental studies around Makum coalfield, Assam, India; Lambert Academic Publishing; ISBN 978-3-8383-2322-0, pp. 16-18.

Chatfield C and Collin A J 1980 Introduction to multivariate analysis; Chapman and Hall, London \& New York; ISBN: 0-412-16030-7.

Dutta Roy R K 1940 A critical study of some Indian coal ashes; The Twelfth Ordinary General Meeting of National Institute of Sciences of India, Kolkatta 6(3) 539-548.

European Commission Directorate-General XIII Telecommunications 1994 The role of fuel additives to control environment emissions and ash fouling, Final report Information Market and Exploitation of Research L-2920 Luxembourg; 4.

Fryda L, Sobrino C, Cieplik M and Van de Kamp W L 2010 Study on ash deposition under oxyfuel combustion of coal/biomass blends; Fuel 89(8) 1889-1902.

Gupta S K, Wall T F, Creelman R A and Gupta R P 1998 Ash fusion temperatures and the transformations of coal ash particles to slag; Fuel Processing Technology 56 33-43.
Huffman G P, Huggins F E and Dunmyre G R 1981 Investigation of the high temperature behavior of coal ash in reducing and oxidizing atmospheres; Fuel 60 585-597.

Heinzel T, Siegle V, Spliethoff H and Hein K R G 1998 Investigation of slagging in pulverized fuel co-combustion of biomass and coal at a pilot-scale test facility; Fuel Processing Technology 54(1-3) 109-125.

IS: 1355.1959 Methods of test for ash of coal and coke.

IS: 12891. 1990 Indian Standard Method of determination of fusibility of ash of coal, coke and lignite.

Kazagic A and Smajevic I 2007 Experimental investigation of ash behaviour and emissions during combustion of Bosnian coal and biomass; Energy 32(10) 2006-2016.

Lloyd W G, Riley J T, Zhou S, Risen M A and Tibbits R L 1993 Ash fusion temperatures under oxidizing conditions; Energy Fuels 7 490-494.

Li H X, Ninomiya Y, Dong Z B and Zhang M X 2006 Applications of the factsage to predict the ash melting behaviour in reducing conditions; Chinese J. Chem. Eng. 14(6) 784-789.

Mishra H K and Ghosh R K 1996 Geology, petrology and utilisation potential of some tertiary coals of northeastern region of India; Int. J. Coal Geol. 30 65-100.

Munir S and Nimmo W 2010 Potential slagging and fouling problems associated with biomass-coal blends in coal-fired boilers; J. Pakistan Inst. Chem. Eng. 38 1-11.

Masia A A T, Buhre B J P, Gupta R P and Wall T F 2007 Characterizing ash of biomass and waste; Fuel Processing Technology 88(11-12) 1071-1081.

Nayak B 2013 Mineral matter and the nature of pyrite in some high sulphur tertiary coals of Meghalaya, northeast India; J. Geol. Soc. India $81203-214$.

Pronobis M 2005 Evaluation of the influence of biomass co-combustion on boiler furnace slagging by means of fusibility correlations; Biomass and Bioenergy 28(4) $375-383$.

Reifenstein A P 1999 Behaviour of selected minerals in an improved ash fusion test: Quartz, potassium feldspar, sodium feldspar, kaolinite, illite, calcite, dolomite, siderite, pyrite and apatite; Fuel 78 1449-1461.

Sharma A, Saikia B K and Baruah B P 2012 Maceral contents of tertiary Indian coals and their relationship with calorific values; Int. J. Inn. Res. Develop. 1(7) 196-203.

Singh M P and Singh A K 2000 Petrographic characteristics and depositional conditions of Eocene coals of platform basins, Meghalaya, India; Int. J. Coal Geol. 42(4) 315-356.

Singh P K, Singh A L, Kumar A and Singh M P 2011 A study on removal of selected major elements from Indonesian coal through bacteria: Environmental implications; Proceedings, International Conference on Energy, Environment, Sustainable Development, Bangkok, Thailand 75 925-935.

Singh P K, Singh A L, Kumar A and Singh M P 2012a Mixed bacterial consortium as an emerging tool to remove hazardous trace metals from coal; Fuel 102 227-230.

Singh P K, Singh M P, Singh A K and Naik A S 2012b Petrographic and geochemical characterization of coals from Tiru valley, Nagaland, NE India; Energy, Exploration and Exploitation 30(2) 171-192.

Singh A K, Singh M P and Singh P K 2013 Petrological investigations of Oligocene coals from foreland basin of northeast India; Energy, Exploration and Exploitation 31(6) 909-936.

Skorupska N M 1993 Coal specifications impact on power station performance; IEACR/52, IEA Coal Research London UK, 120p. 
Song W J, Tang L H, Zhu X D, Wu Y Q, Rong Y Q and Zhu Z B et al. 2009 Fusibility and flow properties of coal ash and slag; Fuel 88 297-304.

Song W J, Tang L H, Zhu X D, Wu Y Q, Zhu Z B and Koyama S 2010 Effect of coal ash composition on ash fusion temperature; Energy Fuels 24 182-189.

Van Dyk J C, Melzer S and Sobiecki A 2006 Mineral matter transformation during Sasol-Lurgi fixed bed dry bottom gasification-utilization of HT-XRD and FactSage modeling; Minerals Eng. 19 1126-1135.

Vassilev S V, Kitano K, Takeda S and Tsurue T 1995 Influence of mineral and chemical composition of coal ashes on their fusibility; Fuel Processing Technology 45(1) $27-51$.

Vassileva C G and Vassilev S V 2002 Relations between ash-fusion temperatures and chemical and mineral composition of some Bulgarian Coals; Bulgarian Academy of Sciences, pp. 61-66.

Vassilev S V and Vassileva C G 2007 A new approach for the classification of coal fly ashes based on their origin, composition, properties and behaviour; Fuel $\mathbf{8 6}$ 1490-1512.

Vassilev S and Vessileva C 2009 A new approach for the combined chemical and mineral classification of the inorganic in the coal. 1. Chemical and mineral classification system; Fuel 88 235-245.

Vamvuka D and Zografos D 2004 Predicting the behaviour of ash from agricultural wastes during combustion; Fuel 83(14-15) 2051-2057.

Ward C R 2002 Analysis and significance of mineral matter in coal seams; Int. J. Coal Geol. 50 135-168.

Wynteri C I, May L, Oliver F W, Hall J A, Hoffman E J, Kumar A and Christopher L 2004 Correlation of coal calorific value and sulphur content with ${ }^{57} \mathrm{Fe}$ Mössbauer spectral absorption; Hyperfine Interactions $\mathbf{1 5 3}$ $147-152$.

Yang J G, Deng F R, Zhao H and Cen K F 2006 Mineral conversion of coal ash in fusing process and the influence to ash-fusion points; Proc. CSEE (Chinese edn) 26 $122-126$. 